\title{
0763 REDUCING THE ROAD TOLL IN SOUTHERN AFRICA THROUGH KNOWLEDGE TRANSFER AND REGULATORY INTERVENTION
}

M Fitzharris*, D Bowman, A Kestler, M Sebego Correspondence: Monash South Africa, Accident Research Centre, 114 Peter Road, Ruimsig, P0 Box X60, Roodepoort, Johannesburg, 1725, South Africa

\subsection{6/ip.2010.029215.763}

Despite the relative lack of motorisation, the African region had the equal highest mortality in 2007 globally, at 32.2 deaths per 100000 population (WHO 2009). With increasing rates of motorisation, traffic-related deaths in sub-Saharan Africa are projected to increase by $80 \%$; in contrast, a $30 \%$ reduction in deaths in high income countries is anticipated (Kopits \& Cropper 2003). The Make Roads Safe Decade of Action campaign has highlighted the urgency of addressing road safety globally. In the adopted Moscow Declaration, as well as the Outcome Document of the UN Economic Commission for Africa Dar es Salaam 2009 Road Safety Symposium, the need for harmonisation of best practice road safety regulations was noted.

The World Report on road traffic injury prevention acknowledged the State of Victoria (Australia) as a world leader in the implementation of road safety programmes. Regulatory strategies, such as seat-belt laws were, and remain, a key plank in addressing the road toll.

This presentation outlines the nature of the road safety situation in one African country, specifically Botswana. A comparative analysis of the scale of road trauma in Botswana and Victoria is presented. Based on this and that of a comparative analysis of the road safety regulatory frameworks in the two jurisdictions, recommendations as to how reductions in road crashes might be achieved in Botswana with limited expenditure are outlined. The findings are also likely to be relevant to other countries within Africa that are grappling with the mounting cost of crashes. 